\title{
Kaunokirjallisuus ja suomalainen yleinen kirjasto
}

\author{
Outi Vuorenrinne
}

Tampereen yliopisto

outivuorenrinne@luukku.com

Vastine Pirjo Tuomen väitöskirjassa Kaunokirjallisuus suomalaiselle yleiselle kirjastolle haasteena, rasitteena ja mahdollisuutena esitettyihin kommentteihin koskien omaa väitöskirjaani.

Asiasanat: aineiston valinta; kirjastohistoria; viihdekirjallisuus; yleiset kirjastot

Olen äskettäin lukenut Pirjo Tuomen viime keväänä tarkastetun väitöskirjan Kaunokirjallisuus suomalaiselle yleiselle kirjastolle haasteena, rasitteena ja mahdollisuutena. Historiallis-argumentativinen tarkastelu suomalaisen yleisen kirjastolaitoksen suhteesta kaunokirjallisuuteen ja kirjalliseen järjestelmään (Tuomi, 2017) ja todennut siinä oman väitöskirjani Nutturat löystymässä. Kirjavalinnan liberalisoituminen Suomen yleisissä kirjastoissa 1960- ja 197o-luvuilla (Vuorenrinne, 2015) joutuneen kohtuuttoman kritiikin kohteeksi heppoisin perustein. Haluan näin julkisesti kommentoida Tuomen esittämää kritiikkiä, koska hänenkin väitöskirjansa on julkisesti luettavissa.

Väitöskirjassaan Tuomi toteaa väitöskirjastani lähdeaineistona seuraavaa:

Myös Outi Vuorenrinteen tuore väitöskirja Nutturat löystymässä: Kirjavalinnan liberalisoituminen Suomen yleisissä kirjastoissa 1960- ja 1970-luvuilla (2015) sivuaa kirjavalinnan kysymyksiä. Vuorenrinteen väitöskirja on oman tutkimukseni kannalta merkittävä siksikin, että 
siinä käsitellään kirjasto- ja kirjallisuudenvalintapoliittisia kysymyksiä lähempänä nykypäivää kuin aikaisemmissa tutkimuksissa. (Tuomi, 2017, s. 19).

Katson kuitenkin, että väitöskirjani Tuomen lähdeaineistona on saanut suhteettoman huomion ottaen huomioon Tuomen väitöskirjan sivumäään suppeuden (230 tekstisivua) ja ajallisesti laajan kattavuuden: Aiheensa käsittelyssä Tuomi lähtee antiikin Kreikan kirjastolaitoksesta ja päätyy nykypäivään. Minun väitöskirjani pysyttelee 1900-luvussa ja painottuu erityisesti vain kahteen vuosikymmeneen, 1960- ja 1970-lukuun. Liekö Tuomelle tullut myös "freudilainen lapsus", kun väitöskirjani kaikesta merkittävyydestään huolimatta on jäänyt pois lähdeluettelosta.

Väitöskirjatyöni pääsee Pirjo Tuomen kritiikin kohteeksi useastikin, mutta nostan esille kärkevimmät:

Kun siis esimerkiksi Vuorenrinne $(2015,4)$ käyttää ilmaisua "ajanvieteeli populaarikirjallisuus” (esim. sama, 28) määrittelemättä, minkälaista kirjallisuutta tarkemmin tarkoittaa, voi olla liian yksioikoista tehdä kovin suoria päätelmiä Kannilan valintapoliittisista kirjallisuusnäkemyksistä ja suhteesta tähän kirjallisuudenlajiin. Esimerkiksi Niemen populaarikirjallisuuden ja Kannilan viihdekirjallisuuden määrittelyistä voidaan löytää samoja elementtejä: kaupalliset tavoitteet, eli pyrkimys mahdollisimman suuren lukijakuntaan tavoittamiseen sekä sisällöllisen jännityksen ja tietynlaisen romanttisen eskapismin tarjoaminen lukijalle (Kannila 1976, 95; Niemi 1975, 18-19.) (Tuomi, 2017, s. 133).

Helle Kannila oli käytännönläheinen toimija, ei teoreetikko, kuten hän itsekin totesi (Cannelin, 1919). Niinpä en katsonut, että olisi ollut relevanttia lähteä tarkastelemaan hänen kirjallisuuskäsityksiään määritelmistä käsin, semminkin kun sekä Kannilan (Kannila, 1967) että Juhani Niemen (1975) määritelmät on esitetty monta vuosikymmentä Helle Kannilan varhaisten kirjallisuuskäsitysten jälkeen. Katson, että määritelmiin sisältyy usein implisiittisesti heijastus määrittelyn ajankohdasta ja historiallisesta kontekstista. Tästä syystä en kelpuuttanut esim. Juhani Niemen viihdekirjallisuusmääritelmää Kannilan varhaisten kirjallisuuskäsitysten ohjenuoraksi. Olin toki tietoinen siitä, löytyyhän Niemen teos lähdeluettelostani. Samasta syystä en myöskään määritellyt työni keskeistä käsitettä tasa-arvo, koska en löytänyt sille kuusikymmenlukulaista määritelmää. En käynyt noutamaan sitä Ranskan vallankumouksen (1789) ajoilta, mistä se varmasti olisi löytynyt. 
Mitä tulee kompetenssiin tehdä suoria päätelmiä Kannilan kirjallisuusnäkemyksistä, joita väitöskirjatyössäni edustaa alaluku 3.2 Helle Kannilan lukemis- ja kirjallisuuskäsitys: 3.2.1 Helle Kannilan aktiivivuosien lukemis- ja kirjallisuuskäsitys (19171963), 3.2.2 Kirjavalinnan ongelmia -teos (1967). Näiden alalukujen sivumäärä on 14 sivua ja näiden lisäksi Helle Kannilan kirjallisuuskäsityksiä käsitellään työssäni kronologisesti aina Helle Kannilan kuolemaan asti 1972. Niin minä kuin lukuisat graduntekijät ja väitöskirjantekijät ennen minua olemme perustaneet päätelmämme Helle Kannilan kirjallisuuskäsityksistä, ei määritelmään, vaan hänen laajaan kirjalliseen aineistoonsa, josta hänen näkemyksensä tulevat hyvin esille. Minun työni lähdeluettelossa on 50 Kannilan lähdeviitettä.

Edelleen Tuomi pyrkii mitätöimään väitöskirjani aiheen, kirjavalinnan liberalisoitumisen tarpeettomana tai tuulesta temmattuna toteamalla:

Vuorenrinne näkee keskustelussa demokratian ja kasvatuksen vastakkainasettelun, josta muodostui kirjavalinnan liberalisointikehityksen kynnyskysymys. Tässä arvokeskustelussa Vuorenrinteen näkemyksen mukaan "demokraattinen palvelulaitoskirjasto tasa-arvoisine ihmiskäsityksineen ja monipuolisine kirjavalintoineen selvisi voittajana yhteiskuntapoliittisessa murroksessa” $(2015,7)$. Tähän on kuitenkin huomautettava, että kirjastojen romaanikirjallisuustarjonta 1960-luvulle tultaessa vastasi hyvin lukijakunnan odotuksia ja lukutottumuksia, kuten edellä esimerkiksi Eskolan ja Kovalan tutkimusten tuloksista voidaan päätellä (luku 5.2). Kirjastojen kirjavalinnan voidaan näin päinvastoin katsoa myötäilleen kirjastonkäyttäjien, eli lukijoiden makumieltymyksiä jo hyvin varhaisessa vaiheessa ennen Vuorenrinteen mainitsemaa yhteiskunnallisen murroksen mukanaan tuomaa "kirjavalinnan liberalisoitumista" ja "palvelukulttuurin muutosta" (Tuomi, 2017, s. 134).

Jos tilanne todella olisi ollut näin auvoinen kuin Tuomi väittää, niin mihin tarvittiin Polva-Golon-Muskett -valtionapujupakkaa 1960-luvun puolivälissä, jossa kirjastontarkastajat yksiselitteisesti kielsivät näiden kirjailijoiden teosten hankinnalta valtionavun, ja eräät kunnat veivät asian oikeuteen ja prosessi johti Korkeimpaan hallinto-oikeuteen? Tämä oikeusprosessi, josta löytyvät arkistolähteet (KHO, 1971), on historiallinen fakta, ei mielipidekysymys. Pirjo Tuomen väitöskirjassa ei kuitenkaan käsitellä tätä tapahtumaa, vaikka siinä kaunokirjallisuus tarjoaa yleiselle kirjastolle haasteen Tuomen väitöskirjan otsikon mukaisesti.

Vuorenrinne toteaa omassa kirjavalinnan liberalisoitumiskehitystä tarkastelleessa tutkimuksessaan, että vasta 1960-luvulla “[k]irjavalinnan 
liberalisoitumiskehityksessä populaarikirjallisuuden hankkimiseen yleisten kirjastojen kokoelmiin alettiin Helle Kannilan jyrkästä vastustuksesta huolimatta suhtautua yhä hyväksyvämmin". Tämä johtui hänen mukaansa yleisen kulttuuripoliittisen keskustelun liberalisoitumisesta. $(2015,7,14$.$) Kuitenkin, kuten aikaisemmin todettiin, kirjastojen kau-$ nokirjallisuuskokoelmien jonkinasteinen viihteellistyminen oli todellisuutta jo 1960-luvulle tultaessa, mikä suuntaus oli nähtävissä esimerkiksi Kannilan kyselyssä 1959. Toisaalta, vaikka mahdollisesti kirjastoihin alettiinkin lisääntyvästi hankkia viihdekirjallisuutta, se ei välttämättä muuttanut kysyntää eikä ehkä ollut myöskään sen seurausta. (Tuomi, 2017, ss. 131-132)

Tässä Tuomi sivuuttaa merkityksettömänä väitöskirjassani kattavasti ja yksityiskohtaisesti (Vuorenrinne, 2015, ss. 290-355) esittämäni kiihkeän keskustelun, jota käytiin kirjastojen henkilökuntalehdissä, Kirjastolehden sivuilla, valtakunnallisilla kirjastopäivillä ja lukuisissa kirjavalintaseminaareissa kahden vuosikymmenen ajan, 1960- ja 1970-luvun, ja jonka tavoitteena oli vastata siihen kysyntään, jota ei-käyttäjät, viihdekirjallisuuden lukijat, kirjaston kirjavalinnalle asettivat. Heitä ei vuonna 1959 oltu tavoitettu, ja heidän tavoittamiseensa kirjavalinnan liberalisoitumiskehityksellä pyrittiin. Kuten kirjastonhoitaja Samuli Nuotio vuonna 1972 totesi: “Tiedän, ja tiedetään, että yhteiskunnassamme on suuri joukko ihmisiä, jotka joutuvat hankkimaan kirjallisen viihteensä ainoastaan kioskeista, koska sitä ei muualta saa. [...] Fiktiivistä, ihmisten viihteekseen lukemaa kirjallisuutta täytyisi kirjastossa kuitenkin olla tarjolla myös niille, jotka eivät omaa 'hyvää kirjallista makua' ja kouluja käyneen harjaantuneisuutta lukemiseen”. (Nuotio, 1972, ss. 11-13) Tämä tavoite saavutettiin, kuten tämän päivän kirjastolaitos osoittaa.

Historiantutkimus on kiehtovaa, koska se on alati elävää ja kehittyvää ja uusille tulkinnoille avointa tietämyksen ja ymmärryksen lisääntyessä, niin myös kirjastohistorian tutkimus. Onhan ajopuuteoriastakin jo luovuttu!

\section{Lähteet}

Cannelin, H. (1919). Yleisten kirjastojen valistustehtävä. Helsingin Sanomat 2.5.1919.

Kannila, H. (1967). Kirjanvalinnan ongelmia : ajatustenaiheita kirjastonhoitajille ja muille kirjojen ystäville. Helsinki: WSOY.

KHO. (1971). Korkeimman hallinto-oikeuden ratkaisujen hakemisto 1933-1968. (P. Valliniemi \& E. Rautalahti, toim.). Helsinki: Suomen lakimiesliiton kustannus.

Niemi, J. (1975). Populaarikirjallisuus Suomessa : huokean viihdekirjallisuuden osakulttuurin erittelyä. Porvoo: WSOY.

Nuotio, S. (1972). Kari J(osef) Kettulalle. Kirjaston kuulumisia, (9), 11-13.

Tuomi, P. (2017). Kaunokirjallisuus suomalaiselle yleiselle kirjastolle haasteena, rasitteena ja mahdollisuutena: historiallis-argumentativinen tarkastelu suomalaisen yleisen kirjastolaitoksen suhteesta 
kaunokirjallisuuteen ja kirjalliseen järjestelmään. Oulu: Oulun yliopisto. http://urn.fi/urn: isbn: 9789526215389 (luettu 30.12.2017)

Vuorenrinne, O. (2015). Nutturat löystymässä. Kirjavalinnan liberalisoituminen Suomen yleisissä kirjastoissa 1960- ja 1970-luvuilla. Tampere: Tampere University Press. http://urn.fi/URN:ISBN: 978-951-44-9818-3 (luettu 18.12.2017) 